\title{
Production of bacterial amylase by Bacillus species isolated from rice husk dumpsites in Sokoto metropolis, Nigeria
}

\author{
S. B. OYELEKE ${ }^{2}$, A. D. IBRAHIM ${ }^{1 *}$, S. B. MANGA ${ }^{1}$, A. B. RABAH ${ }^{1}$, H. AUTA ${ }^{2}$ \\ and F. LADAN ${ }^{1}$
}

\author{
${ }^{I}$ Department of Microbiology, Usmanu Danfodiyo University. Sokoto- Nigeria. \\ ${ }^{2}$ Department of Microbiology, Federal University of Technology, Minna-Nigeria. \\ ${ }^{*}$ Corresponding author, E-mail: aid4life@yahoo.com; Tel: +2348033220699
}

\begin{abstract}
Ten grams (10 g) of soil sample was obtained from a rice husk dumpsite in Sokoto metropolis and analyzed. The species isolated were Bacillus licheniformis, Bacillus lentus and Bacillus megaterium. The Bacillus species isolated were screened for amylolytic activities. The isolate with the widest zone of clearance $\left(\mathrm{A}_{1}\right)$ was selected for further analysis. The highest activity was observed in $B$. licheniformis $(2.00 \pm 0.01 \mathrm{~mm})$ followed by B. lentus $(1.96 \pm 0.40 \mathrm{~mm})$ and $B$. megaterium $(1.70 \pm 0.18 \mathrm{~mm})$ had the least activity. Amylase activity was determined using DNS method. The optimum temperature for the activity of the amylase produced was obtained at $90{ }^{\circ} \mathrm{C}$ with a concentration of $0.373 \mathrm{mg} / \mathrm{ml}$. Optimum $\mathrm{pH}$ activity was obtained at 4.0 with a concentration of $0.376 \mathrm{mg} / \mathrm{ml}$. Bacillus licheniformis has the greatest potential for producing amylase than the other isolates and rice husk can be exploited for amylase production. The B. licheniformis strain produced thermostable alpha-amylase with characteristics suitable for application in starch processing and other food industries.
\end{abstract}

(C) 2011 International Formulae Group. All rights reserved.

Keywords: Amylase, Bacillus licheniformis, DNS method, dumpsites, Rice husk, Sokoto.

\section{INTRODUCTION}

The most important industrial enzymes in use today include proteases, carbohydratehydrolyzing enzymes and ester cleavage fat hydrolyzing enzymes (Negi and Banerjee, 2006). The specific applications of such technical enzymes are in major areas of food processing, beverage production, animal nutrition, leather, paper and pulp, textiles, detergents, etc. Proteolytic enzymes account for nearly $60 \%$ of the industrial enzyme market and are widely used in food industry for cheese ripening, meat tendering, the production of protein hydrolysate and bread making (Poldermans, 1990), and with the advent of new frontiers in biotechnology, the spectrum of amylase and protease application has expanded into many new fields, such as clinical, medicinal and analytical chemistry. To meet the current largely increased demand, studies on the cost-effective production of industrially important enzymes have become the need of today (Negi and Banerjee, 2006).

Agro industrial residues are generally considered the best substrates for the solid state fermentation processes and use of solid state fermentation for the production of enzymes is no exception to that of other forms 
of fermentation. A number of substrate has been employed for the production of microbial enzymes. Some of the substrates that have been used include sugar cane, rice straw, rice husk, banana waste, cassava waste, palm, oil mill waste peanut meal, coconut oil cake, cassava flour, corn flour, steamed rice, starch (Oyeleke and Oduwole, 2009). First of such discovery was made in 1946 when amylase was found to be produced by Bacillus polymyxa and later by another Bacillus species identified as Bacillus cereus (Oyeleke and Oduwole, 2009) other amylolytic enzymes can also be obtainable in Bacillus strains. Amylase is an enzyme that breaks starch down into sugar. Plants and some bacteria also produce amylase. As diastase, amylase was the first enzyme to be discovered and isolated. Specific amylase proteins are designated by different Greek letter. Amylases are the most important enzymes used in biotechnology (Burhan et al., 2003). This study was aimed at isolating bacteria that possesses the capability of producing amylase enzymes from rice husk dumpsites; to exploit rice husk as substrate for the production of amylase, and its properties with regard to the effect of temperature and $\mathrm{pH}$.

\section{MATERIALS AND METHODS \\ Isolation of Bacillus strains from soil sample}

This was carried out in accordance with the method of Oyeleke and Manga (2008). One gram of the soil sample was weighed into $9 \mathrm{ml}$ of sterile distilled water and then placed into a water bath and maintained at $90{ }^{\circ} \mathrm{C}$ for $1 \mathrm{hr}$. Serial dilution of the sample was carried out up to $10^{-5}$. $1 \mathrm{ml}$ of the mixture was inoculated into already prepared plates of nutrient agar fortified with $1 \%$ starch using pour plate method. The poured plate was then incubated at $37{ }^{\circ} \mathrm{C}$ for $24-48 \mathrm{hrs}$. Different Bacillus strains obtained as typical colonies were sub-cultured and thereafter purified several times on fresh nutrient agar plates.

\section{Identification of isolated Bacillus Species}

Morphological and biochemical characterization were carried out. The biochemical test includes Gram staining, spore staining, catalase test, sugar fermentation, starch hydrolysis and citrate utilization, as described by Holt et al. (1994) and Cheesbrough (2003).

\section{Screening the Bacillus Species for Amylolytic Activity}

The amylolytic activity of the isolated organism was determined as described by Bertrand et al. (2004). Loop full of each isolate was streaked aseptically on starch medium. The plate was then incubated at 37 ${ }^{\circ} \mathrm{C}$ for 24 hours. After incubation period, lugol's iodine solution was flooded over the plate, allowed to stand for 20 minutes and the zones of clearance were measured using a meter rule. A zone of clearance formed around the bacterial colonies represents the amylolytic activity of the bacterial species. Though, the amylolytic activity of $B$. licheniformis was not significantly different from that of B. lentus, B. licheniformis was selected for further studies based on suggestions from our previous studies.

\section{Enzyme production and partial purification}

This was carried out according to the methods of Oyeleke and Oduwale (2009). The selected Bacillus isolated was propagated at $37{ }^{\circ} \mathrm{C}$ for $22 \mathrm{hrs}$ in $50 \mathrm{ml}$ of $8 \%(\mathrm{w} / \mathrm{v})$ of rice husk medium in a $250 \mathrm{ml}$ flask. The flask was incubated in a shaker incubator, operated at $120 \mathrm{rpm}$ and at $30{ }^{\circ} \mathrm{C}$. After the incubation period, the resultant broth was centrifuged at $10,000 \mathrm{rpm}$ for $15 \mathrm{~min}$ and the supernatant was collected as the source of crude enzyme (amylase). To partially purify the enzyme extract, a solution of $65 \%(\mathrm{w} / \mathrm{v})$ of sodium sulphate was added to the clarified supernatant, centrifuged at 10,000 rpm and the pellet was suspended in $0.005 \mathrm{M} \mathrm{Na}_{2} \mathrm{HPO}_{4}$ 
(pH 6.0). The purified enzyme extract was used in subsequent assays.

\section{Amylase assay}

Amylase activity was measured as described by Bertrand et al. (2004). A reaction mixture containing $0.5 \mathrm{ml}$ of $1 \%$ (mass per volume ratio) soluble starch solution prepared in $0.2 \mathrm{M}$ citrate buffer and $0.5 \mathrm{ml}$ of appropriately diluted enzyme solution was incubated at $50{ }^{\circ} \mathrm{C}$. After $10 \mathrm{~min}$ of incubation, the reaction was terminated by adding $1.0 \mathrm{ml}$ of DNS solution (1 $\mathrm{g}$ of DNS dissolved in $20 \mathrm{ml}$ of $2 \mathrm{NaOH}$, to which $30 \mathrm{~g}$ of sodium potassium tartarate were added and filled with water to $100 \mathrm{ml}$ ). Reaction mixture was boiled for $15 \mathrm{~min}$ and after cooling, $18 \mathrm{ml}$ of water were added. Absorbance was measured at $540 \mathrm{~nm}$.

\section{Effect of Temperature on Enzyme Activity}

This was carried out in accordance with the methods of Oyeleke and Oduwale (2009). The optimum temperature for activity was determined by assaying activity of the enzyme between $10-100{ }^{\circ} \mathrm{C}$. Thermoability of the amylase was done by maintaining the enzyme solution in water bath at different temperature (30 ${ }^{\circ} \mathrm{C}-90{ }^{\circ} \mathrm{C}$ for 30 minutes). $2 \mathrm{ml}$ of DNS were then added and the absorbance was determined using spectrophotometer at 540 $\mathrm{nm}$.

\section{Effect of pH on Enzyme Activity}

This was carried out in accordance with the methods of Oyeleke and Oduwale (2009). Optimum pH for enzyme (amylase) activity was examined by running the activity assay between $\mathrm{pH}$ range of $2.0-10.0$ on $1 \%$ rice husk medium using $0.05 \mathrm{M} \mathrm{Na}_{2} \mathrm{HPO}_{4}$ as buffer solution the $\mathrm{pH}$ stability was determined by incubating the partially purified enzyme in water bath at $70{ }^{\circ} \mathrm{C}$ for 15 minutes and the residual activity was then measured by adding the DNS reagent and the absorbance for each $\mathrm{pH}$ was determined using spectrophotometer at $540 \mathrm{~nm}$.

\section{Statistical analysis}

The data sets were expressed as mean \pm standard deviation $(\mathrm{n}=3)$. Analysis of variance (ANOVA) was done using One-Way Analysis of Variance to test for the difference in means. Paired Sample T-Test was used to test for the significance between samples at $\alpha(0.05)$ level of significance using the SPSS for Windows, version 15.0. (Chicago IL, USA).

\section{RESULTS}

Three isolates that had creamy colonies with different elevation and width were identified and characterized. They were all catalase positive, gram positive, rod shape, hydrolyze starch (blue blackish colour) and utilized glucose. The bacterial isolates were identified following series of biochemical test as described by Holt et al. (1994): there probable identities are Bacillus licheniformis, Bacillus megaterium and Bacillus lentus (Table 1). Upon screening for amylolytic activity, Bacillus licheniformus (B) had the highest zone of amylase activity $(2.0 \mathrm{~mm})$ and Bacillus megaterium had the least zone of amylase activity $(1.7 \mathrm{~mm})$ as shown in Table 2.

The change in reducing sugar content during fermentation of rice husk by Bacillus licheniformus for amylase production is presented in Figure 1. The concentration of reducing sugar in the production medium increased from 0.499 to $0.566 \mathrm{mg} / \mathrm{ml}$ at $72 \mathrm{hrs}$ of incubation. This reflects that the starch medium was metabolized by Bacillus licheniformus to yield its monomer subunits.

The effect of temperature on amylase activity is presented in Figure 2. Maximum activity for Bacillus licheniformis was obtained at $90{ }^{\circ} \mathrm{C}$ with a reducing sugar concentration of $0.373 \mathrm{mg} / \mathrm{ml}$.

The effect of $\mathrm{pH}$ on amylase activity is presented in Figure 3. The peak amylase activity was observed at $\mathrm{pH} 4.0$ with at concentration of $0.376 \mathrm{mg} / \mathrm{ml}$. 
Table 1: Biochemical identification of bacteria isolated from rice husk dumpsites.

\begin{tabular}{llll}
\hline Rod + & Rod + & Rod + & Gram Reaction \\
\hline $\mathrm{B}_{3}$ & $\mathrm{~B}_{2}$ & $\mathrm{~B}_{1}$ & S/No \\
+ & + & + & Catalase \\
- & - & - & Lactose \\
+ & + & + & Glucose \\
+ & + & + & Sucrose \\
+ & - & - & Citrate \\
+ & + & + & Motility \\
- & - & - & Indole \\
- & + & - & Urease \\
+ & + & + & MR \\
- & - & - & VP \\
+ & + & - & $\mathrm{H}_{2} \mathrm{~S}$ \\
- & - & - & Gas \\
+ & + & + & Spore \\
+ & + & + & Starch hydrolysis \\
\hline Bacillus megaterium & Bacillus lentus & Bacillus licheniformis & Probable Identity \\
\hline
\end{tabular}

Table 2: Amylase activity of Bacillus species isolated from rice husk dumpsites.

\begin{tabular}{lllll}
\hline Isolate Code & Probable identify & No. of plate & Zones of amylase activity \\
\hline $\mathrm{B}_{1}$ & Bacillus licheniformis & Plates 1 & $2.0 \mathrm{~mm}$ & \\
& & Plate 2 & $2.1 \mathrm{~mm}$ & \\
& Plate 3 & $2.0 \mathrm{~mm}$ & \\
& Mean & $=6.1 \mathrm{~mm}$ & $(2.0 \mathrm{~mm})$ \\
\hline $\mathrm{B}_{2}$ & Bacillus lentus & Plate 1 & $1.5 \mathrm{~mm}$ & \\
& & Plate 2 & $2.1 \mathrm{~mm}$ & \\
& Plate 3 & $2.3 \mathrm{~mm}$ & \\
& Mean & $=5.9 \mathrm{~mm}$ & $(1.96 \mathrm{~mm})$ \\
\hline $\mathrm{B}_{3}$ & Bacillus megaterium & Plate 1 & $1.5 \mathrm{~mm}$ & \\
& & Plate 2 & $2.0 \mathrm{~mm}$ & \\
& & Plate 3 & $1.9 \mathrm{~mm}$ & \\
& & Mean & $=5.4 \mathrm{~mm}$ & $(1.7 \mathrm{~mm})$ \\
\hline
\end{tabular}

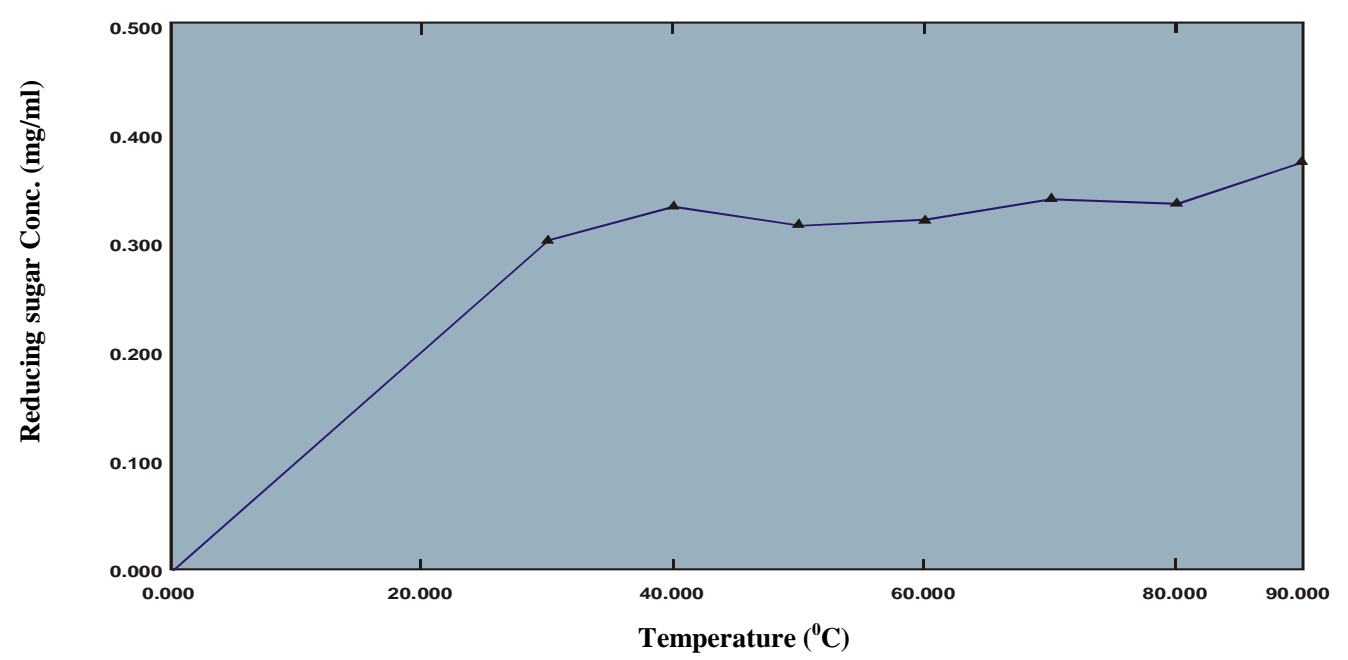

Figure 1: Effect of temperature on amylase enzyme produced by Bacillus licheniformis. 


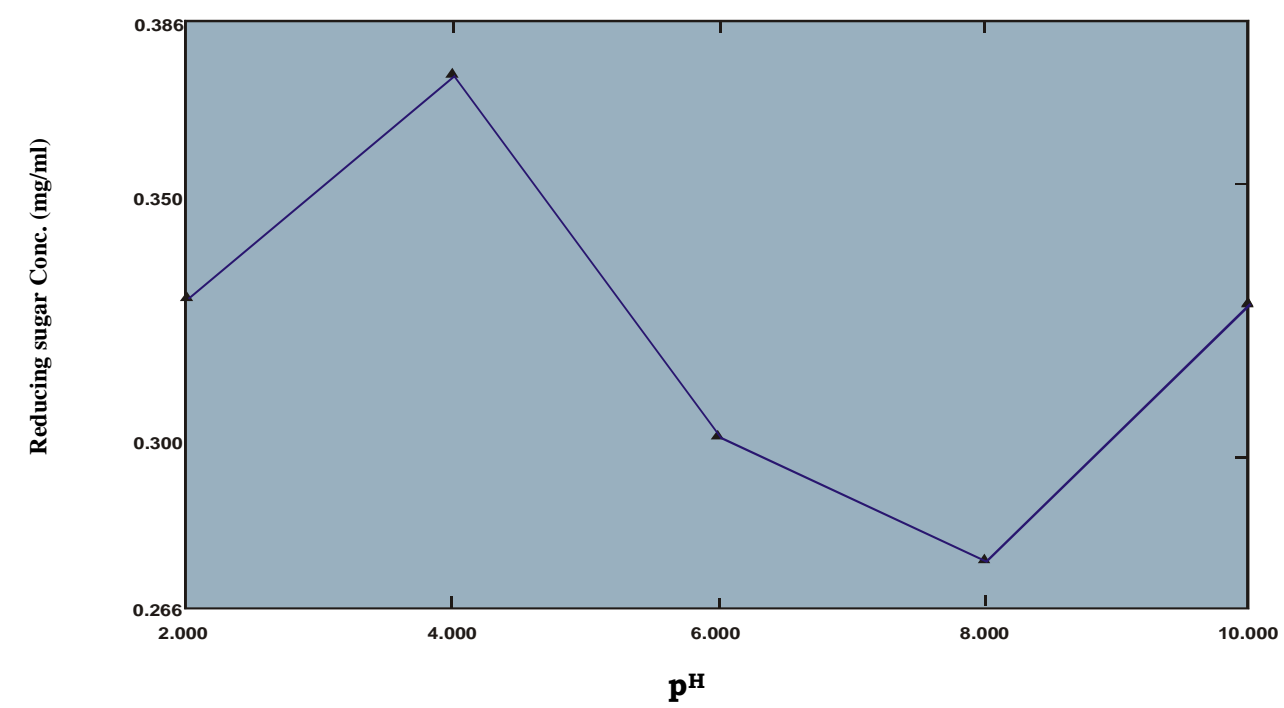

Figure 2: Effect of $\mathrm{pH}$ on amylase enzyme produced by Bacillus licheniformis.

\section{DISCUSSION}

Three strains of Bacillus species were isolated and identified following biochemical test from the rice husk waste dumpsite. These include Bacillus licheniformis $\left(\mathrm{B}_{1}\right)$ Bacillus lentus, $\left(\mathrm{B}_{2}\right)$ and Bacillus megaterium $\left(\mathrm{B}_{3}\right)$. The amylolytic activity of Bacillus isolates following their halos Table 1. Bacillus licheniformis $\left(\mathrm{B}_{1}\right)$ had a mean halo of $2.0 \pm 0.01 \mathrm{~mm}$, Bacillus lentus $\left(\mathrm{B}_{2}\right)$ had a mean of $1.96 \pm 0.40 \mathrm{~mm}$ and Bacillus megaterium had $1.7 \pm 0.18 \mathrm{~mm}$. The strain $\mathrm{B}_{1}$ identities as Bacillus licheniformis was selected for further analysis. Variation in amylolytic halos produced by different strains of Bacillus strain may probably be as a result of difference in their genetic makeup. Since the distinction between the strains lies in the soil origin and taxonomic characteristics of isolates, it was not possible to define whether amylolytic variation between the strains was the consequence of species variability or environmental effect on the same microorganisms (Oyeleke and Oduwole, 2009).

Similar observations were made by Bertrand et al. (2004) from amylolytic halo produced by different yeast strains isolated from starch soils. This result implies that rice husk dumpsites harbor amylase producing Bacillus species with potential for exploitation in an industrial set up after improvement.

The isolated Bacillus licheniformis had the highest frequency, and the least by Bacillus megaterium. The growth and amylase activity of $\mathrm{B}_{1}$ is $8 \%$ in rice husk medium could probably be as a result of its ability to utilize the rice husk as sole carbon source for their growth and metabolism. This agrees with the findings of Oyeleke and Odunwole (2009), Kocher and Katgal (2003), and Oguntimilehin (1993) who investigated cassava waste for the production of bacteria amylase enzyme. This is in contrast with the findings of Teodoro and Martins (2000) that synthesis of carbohydrate degrading enzyme in most species of genus Bacillus leads to catabolic repression by readily metabolizable substrates such as glucose and fructose. This implies that rice husk can be exploited for production of bacterial amylase at no cost.

The amylase in this study exhibited peak amylase activity at $90{ }^{\circ} \mathrm{C}$ with a concentration of $0.37 \mathrm{mg} / \mathrm{ml}$. The amylase in our study seems more thermostable than those reported by other researchers who reported 70 ${ }^{\circ} \mathrm{C}$ (Oyeleke and Odunwole, 2009) and $37{ }^{\circ} \mathrm{C}$ (Dhanya et al., 2006). This implies that the 
amylase in this study could be exploited in starch and food industries whose operations are done at high temperatures.

A pH 4.0 was recorded as the optimum for the production of this amylase. This result is in contrast to that of other researchers. Oyeleke and Odunwole (2009) reported optimum pH 6.5 and 7.5 for Bacillus sp from cassava waste while Anturin et al. (1990) reported a $\mathrm{pH}$ range of $5.5-6.0$ for Bacillus licheniformis. The results suggest that there is a stimulation of enzyme at $\mathrm{pH}$ towards neutrality. Sudharhsan et al. (2007) also made similar observation. Starch and food Industries that exploit amylase for operations in acid environment will find the enzyme in this study worthy harnessing.

\section{Conclusion}

Rice husk waste can be exploited as cheap carbon source for industrial production of amylase from this local Bacillus licheniformis. Further studies may be carried out to ascertain optimum amount of this substrate and inoculums size.

\section{REFERENCES}

Antrim RL, Sotheim BA, Sotheim Autherinen Al, Ginefare J, Karppelin S. 1990. A new Bacillus licheniformis alpha amylase capable of low pH liquefaction. Starch. 43: 355-360.

Bertrand TF, Frederic T, Robert N. 2004. Production and partial characterization of a therhostable amylase from Asscomycetes yeast strain isolated from starchy soil. MacGraw Hill: New York; 53-55.

Burhan A, Nisa U, Gokhan C, Ashabil A, Osmar G. 2003. Enzymatic properties of award thermostable themophilic alkaline and chekato resistant amylase from an alkaphilic Bacillus spp isolate ANT-6. Proc. Biochem., 38: 1397-1403.

Chesbrough M. 2003. District laboratory practical in tropical countries low priced edition. Cambridge University Press: England; 20-35.
Dhanya G, Swetha S, Kesavan MN, Pandey A. 2006. Solid Culturing of Bacillus amyloliquefaciens for Alpha Amylase Production. Food Technol. Biotech., 44(2): 269-274.

Holt JG, Krieg NR, Sneath PHA, Staley JT, Williams ST. 1994. Bergy's Manual of Eterminative Bacteriology $\left(7^{\text {th }}\right.$ edn). Williams and Wilkins; 478-529.

Kocher GS, Katyal P. 2008. Uses of potato starch for extracellular amylase production by yeast isolate. 141004; India; www.cassa.org/New/Biotheiland.

Negi S, Banerjee R. 2006. Optimization of amylase and protease production from Aspergillus awamori in single bioreactor through EVOP Factorial Design Technique. Food Tech. Biotech., 44(2): 257-261.

Oguntimehin GB. 1998. Growth and amylase production by Bacillus licheniformis isolated from cassava processing waste. Nig. Food J., 11: 58-67.

Oyeleke SB, Oduwole AA. 2009. Production of amylase by bacteria isolated from cassava waste dumpsite in Minna, Niger State, Nigeria. Afr. J. Microbiol. Research., 3(4): 143-146.

Oyeleke SB., Manga BS. 2008. Essential of Laboratory Practical in Microbiology $\left(1^{\text {st }}\right.$ edn). Tobest Publisher: Niger State; 3658.

Poldermans B. 1990: Proteolytic Enzymes. In Proteolytic Enzymes in Industry: Production and Applications, $\mathrm{W}$. Gerhartz (ed). VCH Publishers: Weinheim, Germany; 108-123.

Sudharhsan S, Senthilkumar S, Ranjith K. 2007. Physical and nutritional factors affecting the production of amylase from species of bacillus isolated from spoiled food waste. Afr. J. Biotech., 6(4): 430435.

Teodoro S, Martins L. 2000. Culture conditions for the production of thermostable amylase by Bacillus sp. Bra. J. Microbiol., 31: 298-302. 